Article

\title{
The Unbearable Lightness of the Academic Work: The Positive and Negative Sides of Heavy Work Investment in a Sample of Italian University Professors and Researchers
}

\author{
Daniela Converso ${ }^{\circledR}$, Ilaria Sottimano *, Giorgia Molinengo and Barbara Loera \\ Department of Psychology, University of Turin, Via Verdi 10, 10124 Turin, Italy; daniela.converso@unito.it (D.C.); \\ giorgia.molinengo@unito.it (G.M.); barbara.loera@unito.it (B.L.) \\ * Correspondence: ilaria.sottimano@unito.it
}

Received: 9 April 2019; Accepted: 22 April 2019; Published: 24 April 2019

check for updates

\begin{abstract}
Universities perform very demanding tasks within a workplace characterized by a critical psychosocial environment. Against this backdrop, the aim of this study is to extend the current literature on the job sustainability of faculty professors, examine the associations of certain job resources (meaningfulness of work, reward) and job demands (work overload, conflict among colleagues) with workaholism, burnout, engagement. A self-report questionnaire was administered within a public higher education institution in Italy to a sample constituted by 291 professors. The results of path analysis show that meaningfulness of work and reward positively correlate with work engagement, work satisfaction, and psychological wellbeing and ward off emotional exhaustion and intention to leave. Work overload correlates positively with workaholism, work-family conflict and intention to leave and negatively with job satisfaction. Finally, workaholism correlates with work engagement and mediates the relationship between work overload and work-family conflict, emotional exhaustion, and psychological discomfort. The study highlights that to support the work of academic workers and build healthy and sustainable universities, it is necessary to promote job resources and control job demands. Moreover, the study highlights that work engagement and workaholism can be respectively considered as the positive and negative sides of heavy work investment.
\end{abstract}

Keywords: academic work; psychology of sustainability; job engagement; workaholism; JD-R; path analysis

\section{Introduction}

\subsection{Healthy and Sustainable Universities}

As Innstrand et al. (2015) affirm, universities are knowledge-intensive workplaces characterized by a critical psychosocial environment where the quality of knowledge development and transmission depends mainly on the teaching staff's health and wellbeing. On this basis, healthy universities programs have recently been enhanced in Northern Europe and the UK, aimed at "improving health among students and staff, leading to institutional and societal productivity and sustainability" [1]. In accordance with the psychology of sustainability that aims to improve the quality of life [2] and create positive work environments specifically from the organizational positive psychology perspective [3], the healthy universities perspective promotes the creation of an organizational culture that enhances the "wellbeing and sustainability of its community and enables people to achieve their full potential" [4] and defines universities as communities "in which people can thrive and flourish" [5-7]. 
As attention to the health of organizations and to the opportunity to promote health and safety in the workplace along with organizational performance and effectiveness [6] has grown even in the academic context in recent decades, universities face several challenges that resemble those that have characterized the labour market in the last decade in Western countries [8]: many of the characteristics of noble, autonomous, "stress-free" work are, in fact, nowadays undermined, for example, by the reduction of resources that characterize the development of university institutions throughout the Western world. As several scholars have highlighted $[9,10]$, the economic crisis that involved the entire planet in the last 15 years, rendering the situation of large layers of the population more fragile and precarious, has certainly exacerbated critical psychosocial issues in all organizational contexts, and even academic workplaces have most likely been subjected to these influences.

Academic work is, thus, changing, marked by increasing workloads and work hours, growing cuts in research funding, inadequate rewards, job insecurity, the demand for high-quality teaching of large classes, and work-family conflict $[7,11-13]$. Moreover, competitiveness, publication pressures and excessive paperwork (increasing the already intense pressure of the publish or perish situation) strain faculty. In addition, autonomy, societal prestige, and collegial support are decreasing $[14,15]$ while extraneous tasks, such as administrative demands, increase [16]. Several academics perceive these new demands as a threat to two principal characteristics of their work: academic freedom and autonomy [1].

These changes have introduced an added degree of complexity into the working life of university professors and represent sources of stress and burnout. Recently, some studies have observed that university professors experience high levels of burnout [17-19], workaholism and work-family conflict [20,21], finding them to be much more prevalent among university academics than among other workers [21]. A study by Zábrodská et al. [15] highlights, for example, that work-family conflict, which typically afflicts university workers [21], is a major predictor of burnout in faculty members.

The complexity of the psychosocial environment described above is compounded by the non-univocal interpretation by academic workers of what challenging demands might be and what might be the sources of stress or frustration among the different activities that characterize their job [7]. In the light of the job demand-resources (JD-R) [22,23] model, it is therefore crucial to understand which are the core job resources and demands of university professors [1] that can lead, on the one hand, to motivational processes and, on the other hand, to health-impairment processes that reduce and prevent psychological diseases and strengthen positive outcomes to build a sustainable and healthy community.

\subsection{The Job Demands-Resources Model, Burnout and Work Engagement}

The JD-R model postulates that every working activity has some risk factors that can lead to job stress or burnout. These risk factors can be explained in the light of demands and resources: job demands (JD) are those aspects of an occupation that involve the workers in sustaining efforts, both physical or psychological (cognitive and emotional). Examples of JDs are physically demanding tasks or demanding relationships with service users. JD are not always negative, but they may become so, for example, when the demands require a high level of effort although workers obtain relatively low rewards. Job resources (JR) are those dimensions of work (physical or psychosocial or organizational) that can reduce JD, the effects of physiological and psychological demands, and encourage personal and professional growth. Examples are: job security or career opportunities (at the organizational level), supervisor or co-worker social support, work climate (at the interpersonal level), participation or role clarity (at the organizational level), autonomy, or task significance (at the task level) [23].

As previously asserted, this model postulates that there are two psychological processes that can respectively affect job strain (on one side) or motivation (on the other side) $[24,25]$. The first process concerns job strain: chronic JD reduce employees' resources, both mental and physical, and therefore, lead to exhaustion. Consequently, burnout and illness can emerge. This indirectly leads to other consequences, such as low levels of performance [26-29]. The second process concerns motivation: JR can be extremely motivating (intrinsic and extrinsic) and lead to work engagement and indirectly sustain job performance. 
In this direction, several studies have shown that JD and JR can influence employee psychological health. JD are associated with costs in terms of health, for example, in the form of job stress and burnout. Several studies have demonstrated that certain JD, such as excessive workload, affect burnout [27-35] and stress [36]. An excessive workload could, in turn, intensify emotional exhaustion and, consequently, depersonalization. Other JD, such as emotional demands [37], low autonomy, or work-life imbalance [30], also affect burnout. Conversely, JR have a positive impact on organizational outcomes, such as work engagement. Moreover, JR could reduce the negative impact of JD on stress and burnout. For example, social support or autonomy [38,39] could moderate the impact of JD on job stress and burnout, while meaningfulness of work [40], autonomy [41,42] or social support [40,42-45] could protect the ability to work, buffer strain or sustain work engagement.

Finally, JD, especially work overload, are positively and directly related to workaholism, while JR moderate the relationship between workaholism and job demands [46].

\subsection{Workaholism, Burnout and Work-Family Conflict}

Workaholism, recently encountered in several studies conducted in the academic context $[20,21,47,48]$, is often described as a "pattern of heavy work investment, long working hours, working beyond expectations and, especially, an uncontrollable obsession with work" [49], whose antecedents are usually differentiated between the individual and situational [50]. Some researchers define workaholism as a pathology, however, it is not included in the Diagnostic and Statistical Manual of Mental Disorders (DSM-5). Similarly, studies have considered workaholism as a symptom of obsessive-compulsive personality disorder, which is typically characterized by perfectionism and excessive devotion to work [51,52].

Griffiths [49] identified six core dimensions of workaholism:

- $\quad$ salience-work turns into the most important activity in a person's life, dominating his/her thinking, feeling, and behavior;

- mood modification due to work;

- tolerance-gradually increase in daily working time;

- withdrawal symptoms-unpleasant feelings that occur when the person cannot work (because of illness or holidays);

- conflicts, especially in the family context, that concern the person spending too much time at work; and

- relapse-repeated reversion to work.

Some authors note that there are two principal components of workaholism: a behavioral and a psychological one. The former includes working excessively and spending many hours at work. The latter, the psychological or dispositional component, includes being obsessed with work: in other words, the inability to detach from work [53]. More specifically, workaholism is an individual characteristic that leads a person to work too much that does not derive from external necessities $[53,54]$. Workaholism is often associated with several negative outcomes, such as low job satisfaction, stress [55], burnout [50], poor mental and physical health [56-58], and depression [59,60]. Other studies highlight that workaholism is often associated with work-family conflict [61-63]: workaholics spend a lot of their energy and most of their time working without conserving resources for other activities and family.

An interesting topic is the differentiation between workaholism and work engagement: they both indicate high involvement with work, the first as a pathological form of heavy work investment, the second as a healthy one. As highlighted by a recent systematic review [64], it is impossible at this stage to definitively disentangle the commonalities and differences between them. They partially overlap, and the difficulty of drawing a definitive boundary between the two constructs produces seemingly paradoxes, such as "the happy workaholic" [65]. 


\subsection{Aim of the Study}

Informed by the JD-R model and engagement/workaholism research, the aim of this study is to contribute to the current literature on work sustainability pertaining to academic staff by examining the direct and indirect associations of faculty burnout, faculty engagement (as outcomes) and work environment characteristics (demand and resources) with the two dimensions of workaholism (as a predictor). Specifically, we considered two core demands that nowadays negatively characterize academic work, namely workload and conflicts with colleagues [7,13], and two major resources related to the traditional values of faculty work, namely meaningfulness of work and reward [18]. The relationships between the working environment, workaholism, work-family conflict and burnout among this group of workers has, until now, received little attention or research.

Moreover, the study aims to expand research on faculty burnout and engagement by reporting on this harmful syndrome in an under-researched cultural context: Italy, and more specifically, Northwest Italy. The majority of available studies on faculty burnout and psychological strain have been conducted in the United States or in England [15]. Nevertheless, there are some differences in the faculty work and academic competition among countries [2], and these differences could affect academic staff wellbeing [11,15]. As highlighted by several academics [66,67], recent Italian university reforms concerning — among others issues—career advancement and research evaluation, lead to a high degree of competition and pressure: these changes have certainly increased stress and the "workaholic tension" that is likely to culturally affect faculty professors and researchers.

\subsection{Hypotheses}

Specifically, we tested the following hypotheses.

(1) Are resources independently associated with endogenous dependent variables?

(2) Are demands independently associated with endogenous dependent variables?

(3) Are associations between resources and job satisfaction mediated by work engagement?

(4) Are associations between demands and both intention to leave and psychological diseases mediated by work-family conflict and emotional exhaustion?

(5) Are there direct and indirect effects of the two components of workaholism on endogenous dependent variables?

\section{Method}

We administered a self-report questionnaire during June and July 2017, through an online survey developed in order to assess the quality of working life and occupational wellbeing within a large public higher education institution in Northern Italy, considered in the national rankings as one of the best universities in the country.

All professors were properly informed regarding the methods and scope of the study and agreed to participate voluntarily. Professors were invited by e-mail to participate. The e-mail contained a link to the survey and was sent by the research group, thus, maintaining the confidentiality of the users' e-mail addresses.

Ethical approval was obtained from the University Committee for the evaluation of the quality of working life, which was constituted appositely for the project. The study was conducted in accordance with the 1995 Declaration of Helsinki (as revised in Edinburgh in 2000).

\subsection{Participants}

The entire population of the institution comprised 896 professors, just under half (418) completed the questionnaire. Of these, 137 professors did not fill out the questionnaire completely. (The missing answers did not depend on the role, gender or age. Several response biases have also been studied to increase the quality of the data collected. We have removed some records that presented response set (defined as row SD on batteries less than one) and extreme response style (defined as the concentration 
of responses in the extreme categories greater than $40 \%$ of the total answers). The sample is, therefore, constituted by 291 subjects (69.4\% male) ranging in age from 29 to $70(\mathrm{M}=47 \mathrm{SD}=9.9) ; 18.9 \%$ were full professors (FPs), 39.9\% associate professors (APs) and $41.2 \%$ assistant professors (AsPs). Most professors have a permanent contract $(84.7 \%)$ and work full-time $(92.8 \%)$. The average number of years on the job was $17.6(\mathrm{SD}=9.7)$.

\subsection{Measures}

For the detection of the investigated constructs, we have used some of the most popular scales in the literature with respect to work-related stress assessment.

\subsubsection{Antecedents}

Work overload was measured by seven items $(\alpha=0.80)$ developed by Melin [68] (e.g., I work with many different work tasks at the same time.). The responses were given on a four-point scale (range: $0=$ never to $3=$ always). The total score was from 0 to 21 .

Conflict with colleagues was measured with the Multidimensional Organisational Health Questionnaire [69], which contains four items that investigate the degree of conflict inside the workplace (e.g., There are people who are marginalized; $\alpha=0.88$ ). The responses were given on a four-point scale (range: $0=$ never to $3=$ always). The total score: from 0 to 12 .

Meaningfulness of Work was measured with the Copenhagen Psychosocial Questionnaire [70], which contains five items (e.g., I think that my work is meaningful; $\alpha=0.90$ ). The responses were given on a four-point scale (range: $0=$ never to $3=$ always). The total score: from 0 to 15 .

Reward was measured with five items built ad hoc (e.g., To what extent do you feel recognized for your didactic activity? $\alpha=0.69$ ). The responses were given on a four-point scale (range: $0=$ never to $3=$ always). The total score: 0 to 12 .

\subsubsection{Outcomes}

Emotional exhaustion was measured by five items of the Maslach Burnout Inventory [71,72], (e.g., I feel emotionally drained by my work; $\alpha=0.87$ ). The responses were given on a six-point scale (range: $0=$ never to $6=$ every day). The total score: 0 to 30 .

Work engagement was measured by nine items of the Utrecht Work Engagement Scale [73], (e.g., At work, I feel that I am bursting with energy; $\alpha=0.91)$. The responses were given on a six-point scale (range: $0=$ never to $6=$ every day). The total score: 0 to 54 .

Work-family conflict was measured with the SWING [74], which contains five items that investigate negative work home interaction (e.g., You find it difficult to fulfill your domestic obligations because you are constantly thinking about your work; $\alpha=0.89$ ). The responses were given on a four-point scale (range: $0=$ never to $3=$ always). The total score: 0 to 15 .

Intention to leave was measured with four items built ad hoc (e.g., How often, in the last six months, have you thought about changing jobs? $\alpha=0.60$ ). The responses were given on a four-point scale (range: $0=$ never to $3=$ always). The total score: 0 to 12 .

Job satisfaction was measured with a single item (i.e., How satisfied you are with his work?). The responses were given on a 10-point scale (range: $1=$ low to $10=$ high).

Psychological diseases were measured with the General Health Questionnaire (GHQ-12) [75], which contains 12 items (e.g., In the last two weeks, you have been able to concentrate? $\alpha=0.84$ ). The responses were given on a four-point scale (range: $0=$ more than usual to $3=$ less than usual). The total score: 0 to 36 .

Finally, workaholism was measured with 10 items of the Dutch Work Addiction Scale [76] that investigate working excessively (e.g., I continue to work even when others tell me to stop; $\alpha=0.85$ ) and working compulsively (e.g., I feel guilty when I take time off work; $\alpha=0.76$ ). The responses were given on a four-point scale (range: $0=$ never to $3=$ always) Total score: 0 to 30. 


\subsection{Statistical Analyses}

Research hypotheses were tested through path analysis because these models permit the specification of causal relationships or associations among a set of sequentially ordered variables. Each variable in a path analysis model is considered as the dependent variable in a regression analysis in which antecedent variables are treated as independent variables. At the same time, a variable that serves as a dependent variable in one part of the model may serve as an independent variable in another part of the model (endogenous variables). Variables that are not affected by other variables in the model are purely independent (exogenous). The strength of path analysis is that both direct and indirect influences of each independent variable can be examined while controlling for all other variables in the model and considering the residual error of each predictor in the model [77-79].

Guided by the JD-R theory, two path analysis models were used to address the research hypotheses (Figure 1). Specifically, in the first one, we addressed the first four hypotheses:

(1) Are resources independently associated with endogenous dependent variables?

(2) Are demands independently associated with endogenous dependent variables?

(3) Are associations between resources and job satisfaction mediated by work engagement?

(4) Are associations between demands and both intention to leave and psychological diseases mediated by work-family conflict and emotional exhaustion?

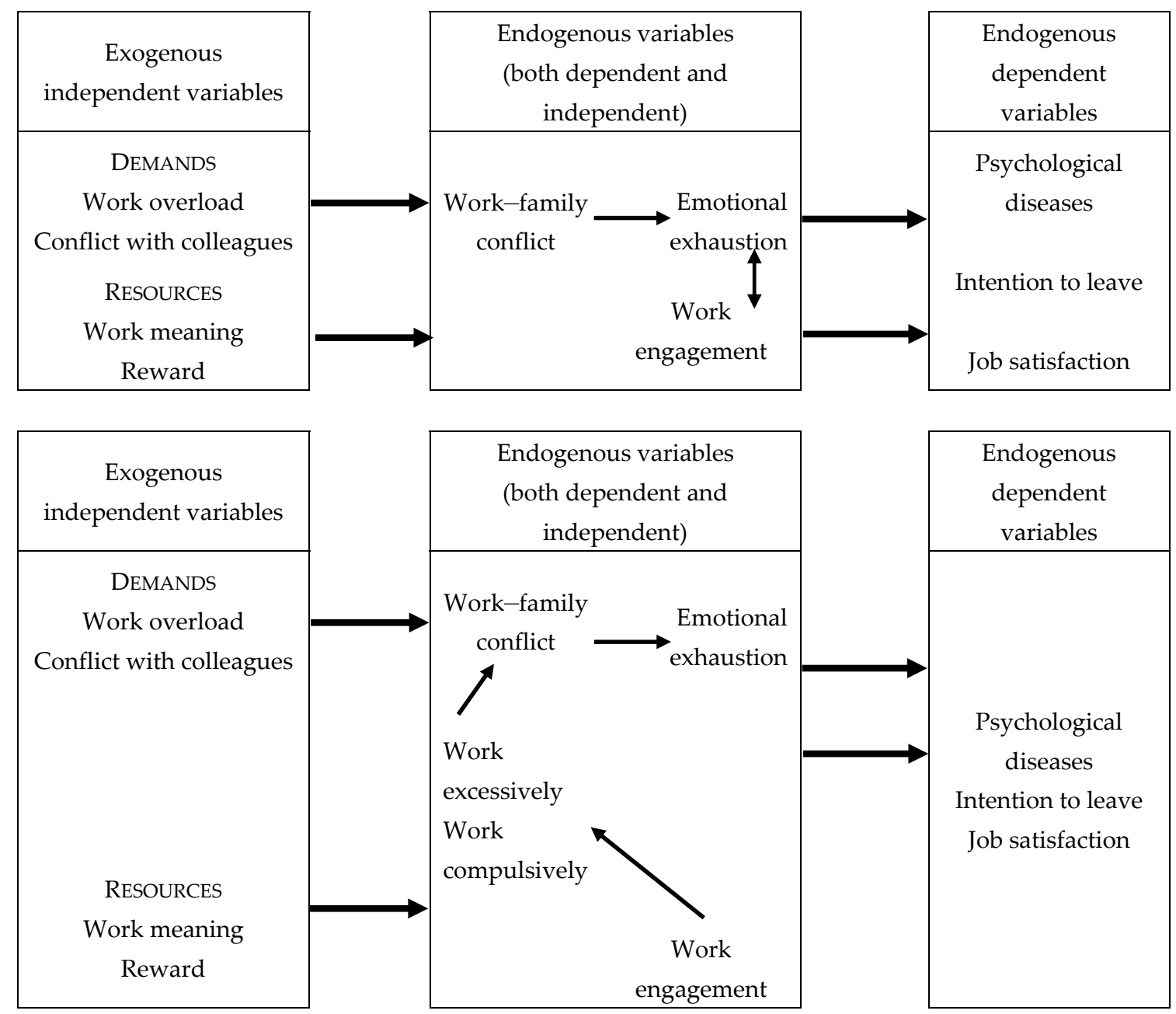

Figure 1. The path analysis models.

In the second model, we inserted the two components of workaholism and tested its direct and indirect effect on endogenous dependent variables. 
Model fit was assessed by a $\chi^{2}$ goodness-of-fit statistic evaluating the degrees of freedom and statistical significance. The chi-square statistic is sensitive to sample size, which means that the model is often rejected when large samples are used [80,81]. When small samples are used, the statistic lacks power and, because of this, may not discriminate between good-fitting models and poor-fitting models [82]. A statistic that minimizes the impact of sample size on the model chi-square is the relative/normed chi-square $\left(\chi^{2} / d f\right)$, proposed by Wheaton et al. [83], for which a ratio lower than two is considered acceptable [84].

In addition, because of their insensitivity to sample size and model misspecification, the following model fit criteria were used: root mean square error of approximation (RMSEA) $<0.08$, comparative fit index $(\mathrm{CFI})>0.95$, and standardized root mean square residual (SRMR) $<0.08$ [85].

The relationships between the study variables and their strengths were estimated using standardized path coefficients and their confidence intervals.

Descriptive statistics were performed using IBM SPSS Statistics (version 24, Armonk, NY, USA), while path analyses were conducted using Mplus 7.0 [79].

\section{Results}

Correlations, means, and standard deviations are presented in Table 1.

Bivariate correlations indicated that all coefficients had the expected signs, with the significant ones ranging from 0.12 to 0.68 . The three endogenous dependent variables (intention to leave, job satisfaction and psychological diseases) are significantly related to all the other variables of the study.

Table 1. Measures description and correlations.

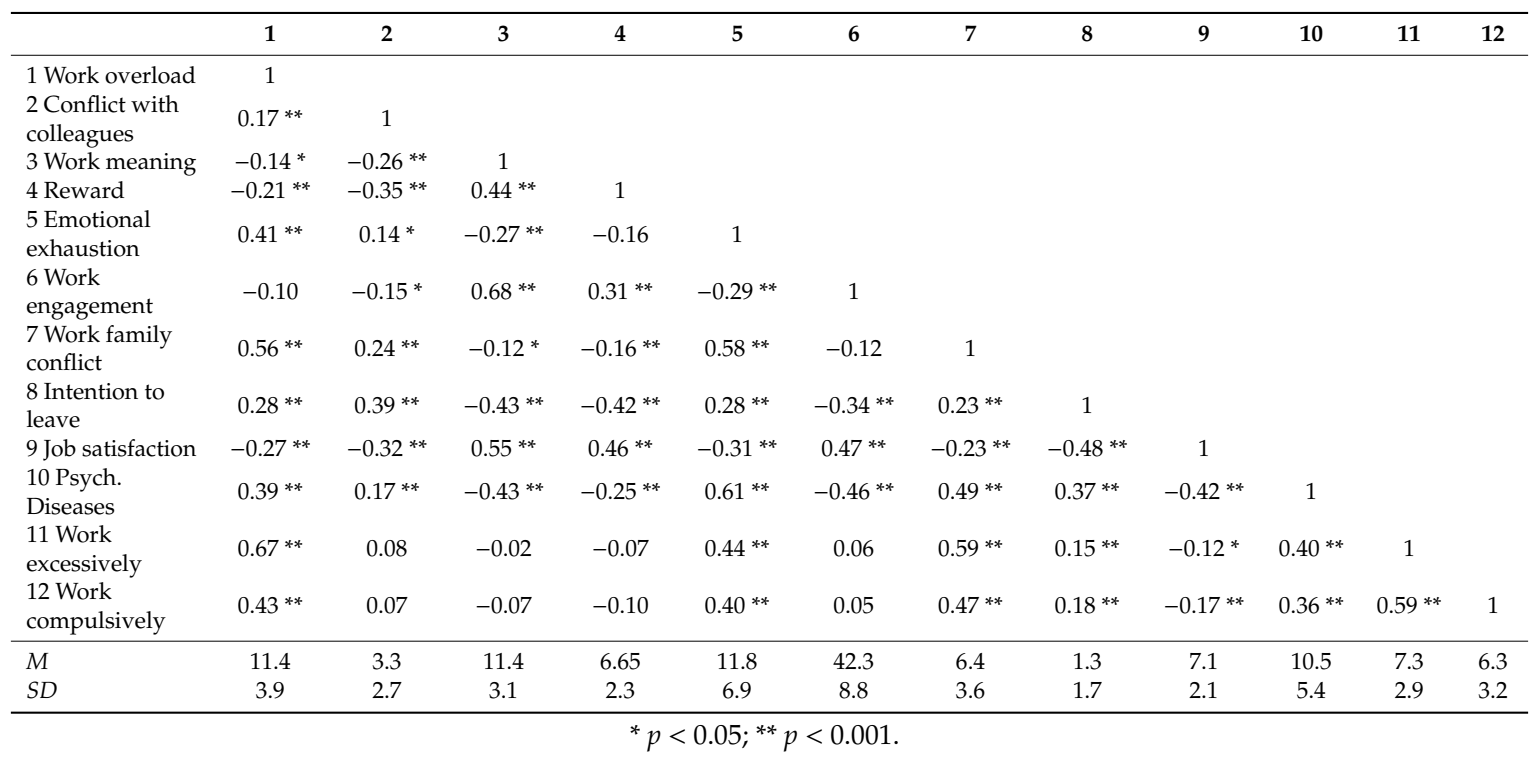

A summary of the statistically significant relationships in the first hypothesis-testing model is presented in Figure 2. The model included all covariances between independent variables and among causal links of interest. Conflict with colleagues on emotional exhaustion, reward on work engagement, both work meaningfulness and emotional exhaustion on intention to leave, emotional exhaustion on job satisfaction, reward and work-family conflict on psychological diseases all had non-significant path coefficients. Finally, psychological diseases were not correlated with either job satisfaction or intention to leave. 


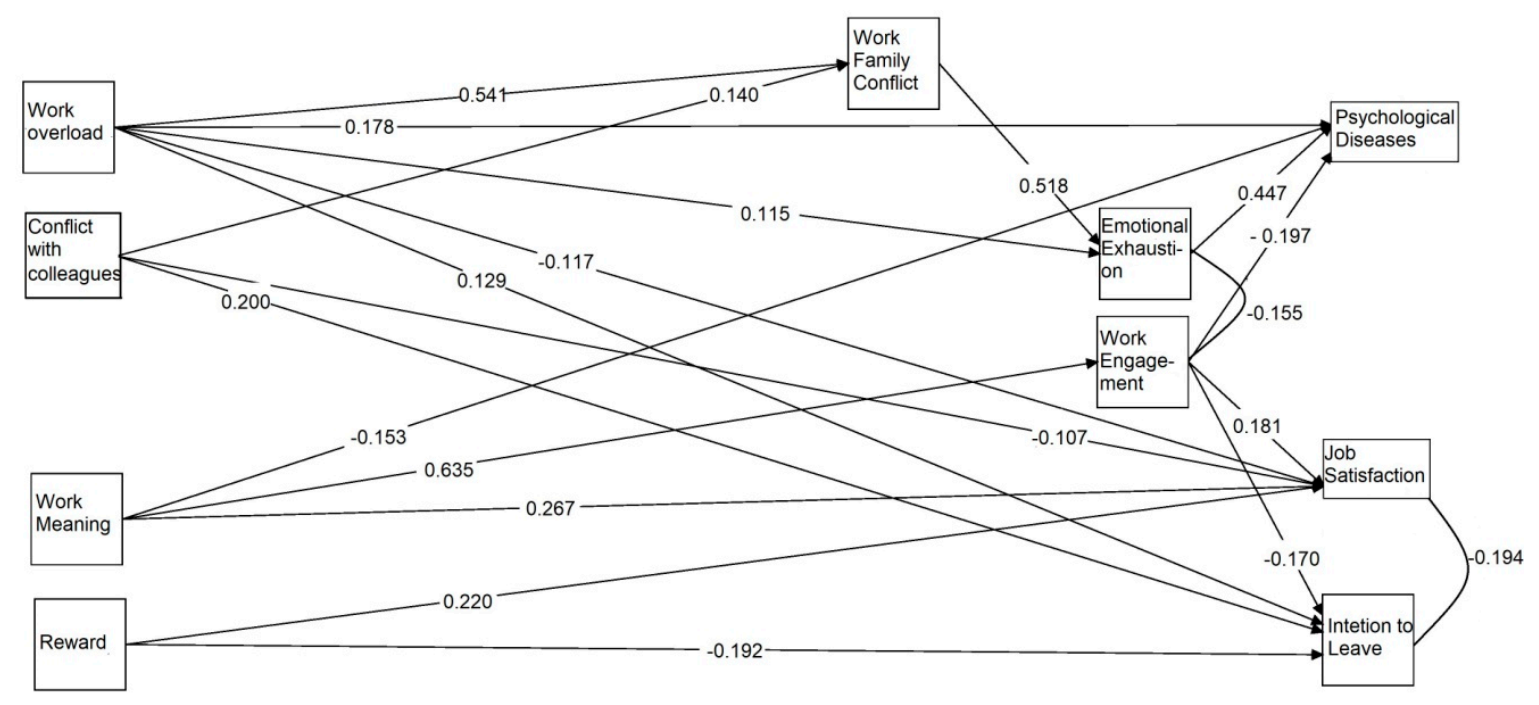

Figure 2. The first tested model.

The difference between "data" (i.e., elements of variance-covariance matrix) and parameters to be estimated was 10, and consequently, model identification was met. The fit indices suggested that the model provided a satisfactory approximation of the data $(\mathrm{CFI}=0.98, \mathrm{RMSEA}=0.07, \mathrm{SRMR}=0.04)$ and only the ratio $\chi^{2} / d f=2.3$ is slightly above the expected value. The R-squared values (Table 2 ) of dependent variables are all high and range from 0.311 to 0.46 .

Work engagement and emotional exhaustion were negatively $(\mathrm{r}=-0.156)$ interrelated, as expected.

Work-family conflict had a strong positive relationship with emotional exhaustion that was also directly influenced by work overload. Work meaningfulness was the only predictor of work engagement. Both work overload and conflict with colleagues were positively related to intention to leave, which was negatively predicted by work engagement and reward.

Job satisfaction was positively predicted by resources (work meaningfulness and reward) and work engagement, while it was negatively predicted by demands (work overload and conflict with colleagues).

Work meaningfulness and work engagement were protective factors against psychological diseases. In contrast, emotional exhaustion and work overload increased the risk of psychological impairment.

The model was then estimated by inserting the two separate components of workaholism, i.e., working excessively and working compulsively (Figure 3), which were only partially interrelated $(r=0.438)$. The model was identified, in fact, the number of free parameters $(n=45)$ is less than the amount of known information from which the parameters were estimated. Fit indices indicated a very good fit $\left(\chi^{2} / d f=1.7, \mathrm{RMSEA}=0.05, \mathrm{SRMR}=0.04, \mathrm{CFI}=0.98\right)$. Only one variable (working compulsively) shows a low R-squared value equal to .18, while the other values range from 0.304 to 0.482 (see Table 2).

Work engagement and emotional exhaustion were negatively $(r=-0.186)$ interrelated, as expected. The results show that only three links among those expected to be significant were not: the direct effect of working excessively on psychological diseases and its relationship with both intention to leave and job satisfaction. Working excessively was predicted by work overload but also by work engagement, thus, confirming Hypothesis 2.

On the other hand, working compulsively was only predicted by work overload and was not increased by work engagement. Both components of workaholism were related to work-home conflict, to work overload and, finally, to conflict with colleagues.

The only direct effect of workaholism on dependent variables was achieved through the impact of excessive work on psychological diseases. 


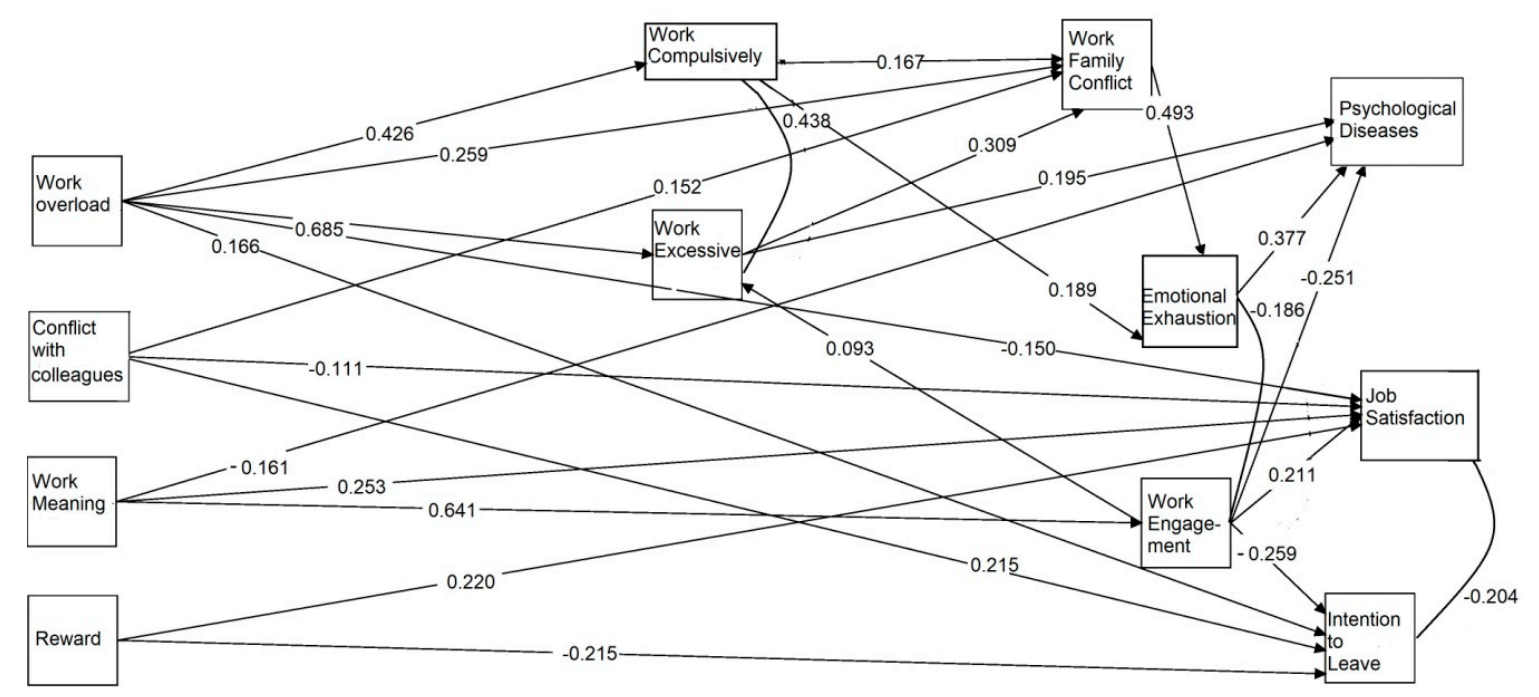

Figure 3. The second tested model.

As in the previous model, work engagement and reward were protective factors that preserve job satisfaction and discourage intention to leave. As in the previous model, work engagement is predicted exclusively by work meaningfulness and not by reward. Work meaningfulness protects both job satisfaction and psychological diseases, while on the contrary, demands (work overload and conflict with colleagues) are risk factors that decrease job satisfaction and increase the intention to leave. After having checked for the effect that work engagement has on excessive work, the protective effects on job satisfaction and psychological diseases remain. Finally, emotional exhaustion contributes to worsening health status.

Table 2. $R^{2}$ values.

\begin{tabular}{ccc}
\hline & First Tested Model & Second Tested Model \\
\cline { 2 - 3 } & $\mathbf{R}^{\mathbf{2}}$ & $\mathbf{R}^{\mathbf{2}}$ \\
\hline Intention to leave & 0.311 & 0.304 \\
Job satisfaction & 0.415 & 0.411 \\
Psychological Diseases & 0.460 & 0.482 \\
Work family conflict & 0.340 & 0.444 \\
Emotional exhaustion & 0.350 & 0.362 \\
Work engagement & 0.416 & 0.410 \\
Working excessively & - & 0.467 \\
Working compulsively & - & 0.182 \\
\hline
\end{tabular}

\section{Discussion}

According to the JD-R model, the considered resources (work meaningfulness and reward) positively correlate with work engagement, work satisfaction, and psychological wellbeing and protect against emotional exhaustion and intention to leave.

More specifically, the meaningfulness of work correlates directly and negatively with emotional exhaustion and psychological disease while positively affecting work satisfaction and work engagement. In turn, work engagement correlates with work satisfaction and protects against psychological distress and intention to leave. Instead, reward directly and positively affects work satisfaction and protects against intention to leave. These findings are in line with those studies that highlight the impact of job resources on psychological wellbeing and work engagement. More specifically, some studies show that meaningfulness of work negatively correlates with perceived stress, burnout, psychological disease [86-88] and job satisfaction [89]. Moreover, our results confirm the existence of the process 
supposed by JD-R concerning motivation: job resources could lead to high work engagement and indirectly impact outcomes, such as job satisfaction, psychological wellbeing, and reduced intention to leave $[29,88,90]$. The results, then, confirm the role of mediator of work engagement [88-91]. In other studies, reward is also confirmed as having a great impact on the job satisfaction of workers [92-94] and protects against intention to leave $[95,96]$.

Again, in line with JD-R model, job demands are associated with costs in terms of health and burnout. More specifically, our results highlight that work overload is directly associated with the negative impact of work on private life (work-family conflict), indirectly associated with emotional exhaustion (through work-family conflict) and, consequently, with psychological diseases. These results are in line with the second process supposed by JD-R: excessive job demands diminish workers' resources, and therefore, lead to a state of emotional exhaustion and, consequently, diseases [26-29]. Our data confirm the literature, highlighting that work overload affects work-family conflict and emotional exhaustion [97-99] and correlates with workaholism [100]. Probably, workers who perform highly demanding tasks struggle to find a balance between work and family roles and are emotionally and physically exhausted. Consequently, their rate of psychological disease increases. Moreover, work overload correlates with job satisfaction, according to the study of Ali and Farooqui [101].

Our results show also that the perception of a conflictual climate correlates positively with work-family conflict and intention to leave but negatively with job satisfaction, confirming that human relations have a high degree of impact on job satisfaction and intention to leave or change jobs [102,103].

Finally, we observed very interesting results about workaholism. Work overload seems to be a predictor of the two dimensions (behavioral and cognitive) of workaholism. Moreover, the compulsive dimension of workaholism correlates positively with emotional exhaustion and negatively with job satisfaction, according to Andreassen et al. [50] and Balducci et al. [55]. Both dimensions of workaholism are associated with work-family conflict and work engagement. According to several studies and to conservation of resources theory (Hobfoll) [104], workaholics expend a lot of time and energy on their work and do not conserve resources and time for their families, thus, experiencing work-family conflict [61-63]. Moreover, workaholics do not get enough rest since they constantly think about work even during their free time $[63,105]$. Based on the loss cycle proposition of COR theory, probably, when workaholic employees perceive a conflict between their work and their family life, they decide to work even harder to find a substitute at work for the losses they experience in their private life.

Another interesting result is the correlation between work engagement and workaholism, especially considering its cognitive dimension, according to Di Stefano and Gaudiino [64], who note that workaholism and work engagement can be respectively described as the pathological and the healthy sides of heavy work investment.

The study has several practical implications. From the perspective of occupational psychological health in the frame of the JD-R model, the study highlights that to support the work of academic workers and build healthy and sustainable universities, it is necessary to promote job resources, especially such traditional academic values [106] as autonomy, reward and meaningfulness of work, which indirectly sustain the work engagement of academic staff. Moreover, it is necessary to control job demands, especially work overload and conflict among colleagues, that affect emotional exhaustion, job satisfaction and psychological health.

As the factors in a healthy organization that must be considered are the individual, the group, the organization and inter-organizational processes [3], accordingly, as in the example of the ARK Study in Norway [107], proper interventions should be developed to reduce the growing competitive climate in universities.

At the individual level, for example, increasing employee participation [3] through enlarging decisional processes can strengthen organizational belonging and identification, support the meaningfulness of academic work and, therefore, engagement [108-110]. Moreover, counseling interventions can promote reflexivity and sustainable career-life projects [111]. At the group level, a healthy group is a team characterized by workplace-relational civility [112] that encourages any 
kind of cooperation, whether for research purposes or teaching activities and can reduce conflicts among colleagues. At the organizational level, healthy universities need sustainability leadership and positive relational management [113] that simultaneously promote positive organizational climates and worker autonomy [114] while they sustain creativity and innovation, two crucial processes related to the academic social mission. As Johnstone and Johnston [115] asserted, workaholism increases when people perceive their working environment as highly pressured, while perceiving working environments as supportive leads to positive emotions and enjoyment in their job.

However, the study has some limitations: even if it helps to explore a little-considered context, the university one, especially in Italy, it involves only academics from an Italian university. In this sense, the results cannot be generalized. Future works could involve university professors from several regions of Italy and from other countries in Europe and abroad.

Second, the use of path analysis has led us to use cause-effect language. However, the study is cross-sectional. Therefore, the direction of the relationships cannot be verified. These results can be considered only as a preliminary evaluation of the hypothesized cause-effect relations.

Third, the estimated path models suffer from omitted variables bias. Finally, the data are self-reported.

To overcome these limitations, future research should apply longitudinal or cross-lagged designs to clearly test cause-effect relations and should include relevant variables, such as personality traits or salaries and employee work histories, as recently emerged in the literature [116].

Moreover, a multi-method design should be used to overcome the limits of self-reported data.

\section{Conclusions}

According to the JD-R model, the study confirms that job resources are very useful to sustain the work of university professors. More specifically, the meaningfulness of work directly correlates with psychological wellbeing, work engagement and, both directly and indirectly through work engagement, with job satisfaction. Similarly, reward positively correlates with job satisfaction and prevents intention to leave. Conversely, conflict among colleagues correlates directly and positively with intention to leave and negatively with job satisfaction. Moreover, conflict among colleagues indirectly impacts on emotional exhaustion through work-family conflict. Finally, work overload directly influences work-family conflict, psychological diseases, job satisfaction (negatively), intention to leave and, both directly and indirectly through WFC, emotional exhaustion.

In addition, with respect to the two dimensions of workaholism, the results of path analysis show that work overload impacts on both dimensions, which mediate the relationship between work overload and work-family conflict, emotional exhaustion (through the compulsive dimension of workaholism) and psychological disease (through working excessively). Finally, working excessively and work engagement correlate with each other. These results contribute to expanding the literature on workaholism, inserting it in the JD-R model. In addition, and above all, the study contributes to increasing knowledge about a peculiar, critical, competitive and highly motivating work context-the university context-which is not widely considered in the literature.

The study has relevant implications for university human resource managers, who can develop interventions and changes aimed at making work more sustainable, in accordance with the psychology of sustainability that also aims to improve the workplace [3]. Moreover, policymakers could allocate more resources to address workplace conditions at universities by increasing the number of jobs, increasing quality research and decreasing competition.

Author Contributions: D.C. and B.L.: design and conceptualization of this study; D.C., I.S., G.M. and B.L.: writing—original draft preparation; D.C.; I.S. and G.M. writing—review and editing; B.L. and G.M.: data curation and formal analysis.

Funding: This research received no external funding.

Conflicts of Interest: The authors declare no conflict of interest. 


\section{References}

1. Innstrand, S.T.; Christensen, M. Academic work engagement, resources and productivity: Empirical evidence with policy implications. Stud. High. Educ. 2018. [CrossRef]

2. Di Fabio, A.M.; Da Maree, J.G. Development of the Life Project Reflexivity Scale: A New Career Intervention Inventory. JCA 2018. [CrossRef]

3. Di Fabio, A.M. Positive Healthy Organizations: Promoting Well-Being, Meaningfulness, and Sustainability in Organizations. Front. Psychol. 2017, 8, 1938. [CrossRef] [PubMed]

4. Healthy Universities. Available online: www.healthyuniversities.ac.uk (accessed on 5 April 2019).

5. Dooris, M.; Doherty, S.; Orm, J. The application of salutogenesis in universities. In The Handbook of Salutogenesis; Mittelmark, M.B., Sagy, S., Eriksson, M., Bauer, G.F., Pelikan, J.M., Lindstrøm, B., Espnes, G.A., Eds.; Springer: Cham, Switzerland, 2017; pp. 237-245.

6. Di Fabio, A.M. The psychology of sustainability and sustainable development for well-being in organizations. Front. Psychol. 2017, 8, 1534. [CrossRef]

7. Converso, D.; Loera, B.; Molinengo, G.; Viotti, S.; Guidetti, G. Not All Academics Are Alike: First Validation of the Academics' Quality of Life at Work Scale (AQoLW). Front. Psychol. 2019, 9, 2408. [CrossRef]

8. Arcangeli, G. Emerging and Re-emerging Organizational Features, Work Transitions, and Occupational Risk Factors: The Good, the Bad, the Right. An Interdisciplinary Perspective. Front. Psychol. 2018, 9, 1533. [CrossRef]

9. Giorgi, G.; Arcangeli, G.; Mucci, N.; Cupelli, V. Economic stress in workplace: The impact of fear the crisis on mental health. Work 2015, 51, 135-142. [CrossRef] [PubMed]

10. Mucci, N.; Giorgi, G.; Roncaioli, M.; Perez, J.F.; Arcangeli, G.; Perez, F.J.F. The correlation between stress and economic crisis: A systematic review. Neuropsychiatr. Dis. Treat. 2016, 12, 983-993. [CrossRef]

11. Shin, J.C.; Jung, J. Academics job satisfaction and job stress across countries in the changing academic environments. High. Educ. 2014, 67, 603-620. [CrossRef]

12. Kinman, G.; Jones, F. A Life Beyond Work? Job Demands, Work-Life Balance, and Wellbeing in UK Academics. J. Hum. Behav. Soc. Environ. 2008, 17, 41-60. [CrossRef]

13. Houston, D.; Meyer, L.H.; Paewai, S. Academic Staff Workloads and Job Satisfaction: Expectations and values in academe. J. High. Educ. Policy Manag. 2006, 28, 17-30. [CrossRef]

14. Fredman, N.; Doughney, J. Academic dissatisfaction, managerial change and neo-liberalism. High. Educ. 2012, 64, 41-58. [CrossRef]

15. Zábrodská, K.; Mudrák, J.; Šolcová, I.; Květon, P.; Blatný, M.; Machovcová, K. Burnout among university faculty: The central role of work-family conflict. Educ. Psychol. 2017. [CrossRef]

16. Tight, M. Higher education research 2000-2010: Changing journal publication patterns. High. Educ. Dev. 2012, 31, 723-740. [CrossRef]

17. Lackritz, J.R. Exploring burnout among university faculty: Incidence, performance, and demographic issues. Teach. Teach. Educ. 2004, 20, 713-729. [CrossRef]

18. Navarro, M.L.A.; Más, M.B. Job stress and burnout syndrome at university: A descriptive analysis of the current situation and review of the principal lines of research. Annu. Clin. Health Psychol. 2010, 6, 67-72.

19. Byrne, M.; Chughtai, A.; Flood, B.; Murphy, E.; Willis, P. Burnout among accounting and finance academics in Ireland. Int. J. Educ. Manag. 2013, 27, 127-142. [CrossRef]

20. Keller, A.C.; Spurk, D.; Baumeler, F.; Hirschi, A. Competitive climate and workaholism: Negative sides of future orientation and calling. Pers. Individ. Differ. 2016, 96, 122-126. [CrossRef]

21. Torp, S.; Lysfjord, L.; Midje, H.H. Workaholism and work-family conflict among university academics. High. Educ. 2018, 76, 1071-1090. [CrossRef]

22. Demerouti, E.; Bakker, A.B.; Nachreiner, F.; Schaufeli, W.B. The job demands-resources model of burnout. J. Appl. Psychol. 2001, 86, 499-512. [CrossRef]

23. Bakker, A.B.; Demerouti, E. The Job Demands-Resources Model: State of Art. J. Manag. Psychol. 2007, 22, 309-328. [CrossRef]

24. Shaufeli, W.B.; Taris, T.W. A critical review of the Job Demands-Resources Model: Implications for improving work and health. In Bridging Occupational, Organizational and Public Health: A Transdisciplinary Approach; Bauer, G.F., Hamming, O., Eds.; Springer: Dordrecht, The Netherlands, 2014; pp. 43-68. 
25. Bakker, A.B.; Demerouti, E. The Job-Demand Resources Theory: Taking stock and looking forward. J. Occup. Health Psychol. 2017, 22, 273-285. [CrossRef] [PubMed]

26. Leiter, M.P. Burnout as a developmental process: Consideration of models. In Professional Burnout: Recent Developments in Theory and Research; Schaufeli, W.B., Maslach, C., Marek, T., Eds.; Taylor and Francis: Washington, DC, USA, 1993; pp. 237-250.

27. Demerouti, E.; Bakker, A.B.; Nachreiner, F.; Schaufeli, W.B. A model of burnout and life satisfaction among nurses. J. Adv. Nurs. 2000, 32, 454-464. [CrossRef] [PubMed]

28. Demerouti, E.; Bakker, A.B.; De Jonge, J.; Janssen, P.P.; Schaufeli, W.B. Burnout and engagement at work as a function of demands and control. Scand. J. Work Environ. Health 2001, 27, 279-286. [CrossRef]

29. Geurts, S.A.E.; Sonnentag, S. Recovery and explanatory mechanism in the relation between acute stress reactions and chronic health impairment. Scand. J. Work Environ. Health 2006, 32, 482-492. [CrossRef] [PubMed]

30. Adil, M.S.; Baig, M. Impact of job demands-resources model on burnout and employee's well-being: Evidence from the pharmaceutical organisations of Karachi. IIMB Manag. Rev. 2018, 30, 119-133. [CrossRef]

31. Upadyaya, K.; Vartiainen, M.; Salmela-Aro, K. From job demands and resources to work engagement, burnout, life satisfaction, depressive symptoms, and occupational health. Burn. Res. 2016, 3, 101-108. [CrossRef]

32. Karkar, A.; Dammang, M.; Bouhaha, B. Stress and burnout among hemodialysis nurses: A single-center, prospective survey study. Saudi J. Kidney Dis. Transplant. 2015, 26, 12. [CrossRef]

33. Van Droogenbroeck, F.; Spruyt, B.; Vanroelen, C. Burnout among senior teachers: Investigating the role of workload and interpersonal relationships at work. Teach. Educ. 2014, 43, 99-109. [CrossRef]

34. Xiaoming, Y.; Ma, B.J.; Chang, C.L.; Shieh, C.J. Effects of workload on burnout and turnover intention of medical staff: A study. Stud. Ethno-Med. 2014, 8, 229-237. [CrossRef]

35. Azeem, S.M.; Nazir, N.A.; Zaidi, Z.B.A.; Akhtar, N. Role of Stress and Burnout among Nurses in the Private Hospitals. Int. J. Acad. Bus. Soc. Sci. 2014, 4, 420-428. [CrossRef]

36. Borteyrou, X.; Truchot, D.; Rascle, N. Development and validation of the work stressor inventory for nurses in Oncology: Preliminary findings. J. Adv. Nurs. 2014, 70, 443-453. [CrossRef]

37. Montgomery, A.; Spânu, F.; Băban, A.; Panagopoulou, E. Job demands, burnout, and engagement among nurses: A multi-level analysis of ORCAB data investigating the moderating effect of teamwork. Burn. Res. 2015, 2, 71-79. [CrossRef]

38. Guidetti, G.; Converso, D.; Loera, B.; Viotti, S. Concerns about change and employee wellbeing: The moderating role of social support. J. Workplace Learn. 2018, 30, 216-228. [CrossRef]

39. Converso, D.; Sottimano, I.; Guidetti, G.; Loera, B.; Cortini, M.; Viotti, S. Aging and Work Ability: The Moderating Role of Job and Personal Resources. Front. Psychol. 2018, 8, 10. [CrossRef]

40. Sottimano, I.; Viotti, S.; Guidetti, G.; Converso, D. Protective factors for work ability in preschool teachers. Occup. Med. 2017, 67, 301-304. [CrossRef]

41. Salminen, S.R.; Mäkikangas, A.; Feldt, T. Job Resources and Work Engagement: Optimism as Moderator Among Finnish Managers. J. Eur. Psychol. Stud. 2014, 5, 69-77.

42. Alzyoud, A.A.Y.; Othman, S.Z.; Mohd, M.F.I. Examining the Role of Job Resources on Work Engagement in the Academic Setting. Asian Soc. Sci. 2015, 11, 103. [CrossRef]

43. Martini, M.; Loera, B.; Converso, C. Users' Gratitude as a source of support for Social-Health Operators First validation of the Perceived Gratitude Scale (PGrate). Appl. Psychol. Bull. (Bollettino di Psicologia Applicata) 2015, 63, 23-33.

44. Loera, B.; Martini, M.; Viotti, S.; Converso, D. Users' Support as a Social Resource in Educational Services: Construct Validity and Measurement Invariance of the User-Initiated Support Scale (UISS). Front. Psychol. 2016, 7, 1248. [CrossRef]

45. Martini, M.; Viotti, S.; Converso, D.; Battaglia, J.; Loera, B. When social support by patrons protects against burnout: A study among Italian public library workers. J. Librariansh. Inf. Sci. 2018, 1-12. [CrossRef]

46. Choi, Y. The Differences between Work Engagement and Workaholism, and Organizational Outcomes: An Integrative Model. Soc. Behav. Personal. Int. J. 2013, 41, 1655-1665. [CrossRef]

47. Bartczak, M.; Ogińska-Bulik, N. Workaholism and Mental Health among Polish Academic Workers. Int. J. Occup. Saf. Ergon. 2012, 18, 3-13. [CrossRef] 
48. Hogan, V.; Hogan, M.; Hodgins, M. A study of workaholism in Irish academics. Occup. Med. 2016, 66, 460-465. [CrossRef]

49. Griffiths, M.D. Workaholism-A 21st-century addiction. Psychol. Bull. Br. Psychol. Soc. 2011, 24, 740-744.

50. Andreassen, C.S.; Ursin, H.; Eriksen, H.R. The relationship between strong motivation to work, "workaholism", and health. Psychol. Health 2007, 22, 615-629. [CrossRef]

51. Hertler, S.C. Understanding Obsessive-Compulsive Personality Disorder: Reviewing the Specificity and Sensitivity of DSM-IV Diagnostic Criteria. SAGE Open 2013, 1-10. [CrossRef]

52. Fineberg, N.A.; Reghunandanan, S.; Kolli, S.; Atmaca, M. Obsessive-compulsive (anankastic) personality disorder: Toward the ICD-11 classification. Braz. J. Psychiatry 2014, 36, 40-50. [CrossRef]

53. Taris, T.W.; Geurts, S.A.E.; Schaufeli, W.B.; Blonk, R.W.B.; Lagerveld, S.E. All day and all of the night: The relative contribution of two dimensions of workaholism to well-being in self-employed workers. Work Stress 2008, 22, 153-165. [CrossRef]

54. Ng, T.W.H.; Sorensen, K.L.; Feldman, D.C. Dimensions, antecedents, and consequences of workaholism: A conceptual integration and extension. J. Organ. Behav. 2007, 28, 111-136. [CrossRef]

55. Balducci, C.; Avanzi, L.; Fraccaroli, F. The Individual "Costs" of Workaholism: An Analysis Based on Multisource and Prospective Data. J. Manag. 2018, 44, 2961-2986. [CrossRef]

56. Clark, M.; Michel, J.; Zhdanova, L.; Pui, S.; Baltes, B. All work no play? A meta-analytic examination of the correlates and outcomes of workaholism. J. Manag. 2014, 42, 1836-1873. [CrossRef]

57. Midje, H.H.; Nafstad, I.T.; Syse, J.; Torp, S. Workaholism and Mental Health Problems Among Municipal Middle Managers in Norway. J. Occup. Environ. Med. 2014, 56, 1042-1051. [CrossRef]

58. Schaufeli, W.B.; Shimazu, A.; Taris, T. Being driven to work excessively hard: The evaluation of a two-factor measure of workaholism in the Netherlands and Japan. Cross-Cult. Res. 2009, 43, 320-348. [CrossRef]

59. Nie, Y.; Sun, H. Why do workaholics experience depression? A study with Chinese University teachers. J. Health Psychol. 2016, 21, 2339-2346. [CrossRef]

60. Bakker, A.B.; Demerouti, E.; Oerlemans, W.; Sonnentag, S. Workaholism and daily recovery: A day reconstruction study of leisure activities. J. Organ. Behav. 2013, 34, 87-107. [CrossRef]

61. Bonebright, C.A.; Clay, D.L.; Ankenmann, R.D. The relationship of workaholism with work-life conflict, life satisfaction, and purpose in life. J. Couns. Psychol. 2000, 47, 469-477. [CrossRef]

62. Taris, T.W.; Schaufeli, W.B.; Verhoeven, L.C. Workaholism in the Netherlands: Measurement and implications for job strain and work-non work conflict. Appl. Psychol. Int. Rev. 2005, 54, 37-60. [CrossRef]

63. Hakanen, J.; Peeters, M. How Do Work Engagement, Workaholism, and the Work-to-Family Interface Affect Each Other? A 7-Year Follow-Up Study. J. Occup. Environ. Med. 2015, 57, 601-609. [CrossRef]

64. Di Stefano, G.; Gaudiino, M. Workaholism and work engagement: How are they similar? How are they different? A systematic review and meta-analysis. Eur. J. Organ. Psychol. 2019, 1-19. [CrossRef]

65. Friedman, S.D.; Lobel, S. The Happy Workaholic: A role model for employees. Acad. Manag. Perspect. 2003, 17,87-98. [CrossRef]

66. Baccini, A. Napoléon et l'évaluation bibliométrique de la recherche: Considérations sur la réforme de l'université et sur l'action de l'agence nationale d'évaluation en Italie/Napoleon and the Bibliometric Evaluation of Research: Considerations on University Reform and the Action of the National Evaluation Agency in Italy. Can. J. Inf. Libr. Sci. 2016, 40, 37-57.

67. Geuna, A.; Piolatto, M. Research assessment in the UK and Italy: Costly and difficult, but probably worth it (at least for a while). Res. Policy 2016, 45, 260-271. [CrossRef]

68. Melin, M.; Astvik, W.; Bernhard-Oettel, C. New work demands in higher education. A study of the relationship between excessive workload, coping strategies and subsequent health among academic staff. Qual. High. Educ. 2014, 20, 290-308. [CrossRef]

69. Avallone, F.; Paplomatas, A. Salute Organizzativa. Psicologia del Benessere nei Contesti Lavorativi; Cortina Raffaello: Roma, Italy, 2005.

70. Kristensen, T.S.; Hannerz, H.; Høgh, A.; Borg, V. The Copenhagen Psychosocial Questionnaire (COPSOQ)—A tool for the assessment and improvement of the psychosocial work environment. Scand. J. Work Environ. Health 2005, 31, 438-449. [CrossRef]

71. Maslach, C.; Jackson, S.E.; Leiter, M.P. Maslach Burnout Inventory Manual, 3rd ed.; Consulting Psychologists Press: Palo Alto, CA, USA, 1996. 
72. Loera, B.; Converso, D.; Viotti, S. Evaluating the Psychometric Properties of the Maslach Burnout Inventory-Human Services Survey (MBI-HSS) among Italian Nurses: How Many Factors Must a Researcher Consider? PLOS ONE 2014, 9, e114987. [CrossRef]

73. Schaufeli, W.; Bakker, A. Utrecht Work Engagement Scale; Occupational Health Psychology Unit, Utrecht University: Utrecht, The Netherlands, 2004.

74. Wagena, E.; Geurts, S.A.E. SWING: Ontwikkeling en validering van de 'Survey Werk-thuis Interferentie-Nijmegen' [SWING: Development and validation of the 'Survey work-home interferenceNijmegen']. Gedrag Gezondheid 2004, 28, 138-158.

75. Goldberg, D. General Health Questionnaire (GHQ-12); NFER-Nelson: Windsor, UK, 1992.

76. Robinson, B.E. The Work Addiction Risk Test: Development of a tentative measure of workaholism. Percept. Mot. Skills 1999, 88, 199-210. [CrossRef]

77. Bollen, K.A. Structural Equations with Latent Variables; Wiley: Hoboken, NJ, USA, 1989.

78. Bollen, K.A. Foundations in Structural Equations Models; Wiley: New York, NY, USA, 2013.

79. Muthén, L.K.; Muthén, B.O. Mplus User's Guide, 5th ed.; Muthén \& Muthén: Los Angeles, CA, USA, 2001-2009.

80. Bentler, P.M.; Bonett, D.G. Significance tests and goodness of fit in the analysis of covariance structures. Psychol. Bull. 1980, 88, 588-606. [CrossRef]

81. Jöreskog, K.G.; Sörbom, D. LISREL 8: Structural Equation Modeling with the SIMPLIS Command Language; Scientific Software International: Lincolnwood, IL, USA, 1993.

82. Kenny, D.A.; McCoach, D.B. Effect of the Number of Variables on Measures of Fit in Structural Equation Modeling. Struct. Equ. Model. A Multidiscip. J. 2003, 10, 333-351. [CrossRef]

83. Wheaton, B.; Muthén, B.; Alwin, D.F.; Summers, G.F. Assessing Reliability and Stability in Panel Models. In Sociological Methodology; Heise, D.R., Ed.; Jossey Bass: San Francisco, CA, USA, 1977; pp. 84-136.

84. Tabachnick, B.G.; Fidell, L.S. Using Multivariate Statistics, 5th ed.; Allyn \& Bacon: Boston, MA, USA, 2007.

85. Hu, L.T.; Bentler, P.M. Evaluating model fit. In Structural Equation Modeling in Psychological Research: Issues and Applications; Hoyle, R., Ed.; Sage: Thousand Oaks, CA, USA, 1995; pp. 76-99.

86. Borritz, M.; B??ltmann, U.; Rugulies, R.; Christensen, K.B.; Villadsen, E.; Kristensen, T.S. Psychosocial Work Characteristics as Predictors for Burnout: Findings from 3-Year Follow Up of the PUMA Study. J. Occup. Environ. Med. 2005, 47, 1015-1025. [CrossRef]

87. Moreno-Milan, B.; Cano-Vindel, A.; Lopez-Dóriga, P.; Medrano, L.A.; Breitbart, W. Meaning of work and personal protective factors among palliative care professionals. Palliat. Support. Care 2019, 1-7. [CrossRef]

88. Hakanen, J.J.; Schaufeli, W.B.; Ahola, K. The Job Demands-Resources model: A three-year cross-lagged study of burnout, depression, commitment, and work engagement. Work Stress 2008, 22, 224-241. [CrossRef]

89. Chevalier, S.; Fouquereau, E.; Bénichoux, F.; Colombat, P. Beyond working conditions, psychosocial predictors of job satisfaction, and work engagement among French dentists and dental assistants. J. Appl. Biobehav. 2018, 24, e12152. [CrossRef]

90. Saks, A.M. Antecedents and consequences of employee engagement. J. Manag. Psychol. 2006, 21, 600-619. [CrossRef]

91. Jung, H.S.; Yoon, H.H. What does work meaning to hospitality employees? The effects of meaningful work on employees' organizational commitment: The mediating role of job engagement. Int. J. Hosp. Manag. 2016, 53, 59-68. [CrossRef]

92. Ali, R.; Ahmed, M.S. The Impact of Reward and Recognition Programs on Employee's Motivation and Satisfaction: An Empirical Study. IRBRP 2009, 5, 270-279.

93. Jehanzeb, K.; Rasheed, M.F.; Rasheed, A.; Aamir, A. Impact of Rewards and Motivation on Job Satisfaction in Banking Sector of Saudi Arabia. IJBSS 2012, 3, 272-278.

94. Zaraket, W.S.; Saber, F. The Impact of Financial Reward on Job Satisfaction and Performance: Implications for Blue Collar Employees. China-USA Bus. Rev. 2017, 16, 369-378.

95. Li, J.; Galatsch, M.; Siegrist, J.; Müller, B.H.; Hasselhorn, H.M. Reward frustration at work and intention to leave the nursing profession-Prospective results from the European longitudinal NEXT study. Int. J. Nurs. Stud. 2011, 48, 628-635. [CrossRef]

96. Park, J.H.; Park, M.J.; Hwang, H.Y. Intention to leave among staff nurses in small- and medium-sized hospitals. J. Clin. Nurs. 2019, 28, 1856-1867. [CrossRef] 
97. Karapete, O.M. The effects of work overload and work-family conflict on job embeddedness and job performance: The mediation of emotional exhaustion. IJCHM 2013, 25, 614-634.

98. Qaiser, S.; Gulzar, A.; Hussain, W.; Shabbir, H. Influence of Work Overload, Work-Family Conflicts and Negative Affectivity on Job Embeddedness and Emotional Exhaustion: The Moderating Role of Coworker Support (Case of Health Management). J. Sci. Rep. 2015, 7, 75-85. [CrossRef]

99. Tabassum, H.; Farooq, Z.; Fatima, I. Work Family Conflict, Perceived Work Overload and Work Exhaustion in Employees of Banking Sector. Pak. J. Commer. Soc. Sci. 2017, 11, 439-451.

100. Spagnoli, P.; Balducci, C.; Kovalchuk, L.S.; Maiorano, F.; Buono, C. Are Engaged Workaholics Protected against Job-Related Negative Affect and Anxiety before Sleep? A Study of the Moderating Role of Gender. Int. J. Environ. Res. Public Health 2018, 15, 1996. [CrossRef]

101. Ali, S.; Farooqui, Y.A. Effect of Work Overload on Job Satisfaction, Effect of Job Satisfaction on Employee Performance and Employee Engagement (A Case of Public Sector University of Gujranwala Division). IJSE 2014, 5, 23-30.

102. Goi, M.T. Impact of Organizational Climate on Intentions to Leave and Job Satisfaction. World J. Manag. 2014, 5, 14-24.

103. Stone, P.W.; Mooney-Kane, C.; Larson, E.L.; Pastor, D.K.; Zwanziger, J.; Dick, A.W. Nurse Working Conditions, Organizational Climate, and Intent to Leave in ICUs: An Instrumental Variable Approach. Health Serv. 2007, 42, 1085-1104. [CrossRef]

104. Hobfol, S.E.; Shirom, A. Conservation of resources theory: Applications to stress and management in the workplace. In Handbook of Organizational Behavior; Golembiewski, R.T., Ed.; Marcel Dekker: New York, NY, USA, 2001; pp. 57-80.

105. Van Wijhe, C.; Peeters, M.; Schaufeli, W. Irrational Beliefs at Work and Their Implications for Workaholism. J. Occup. Rehabil. 2013, 23, 336-346. [CrossRef]

106. Anthun, K.S.; Innstrand, S.T. The predictive value of job demands and resources on the meaning of work and organisational commitment across different age groups in the higher education sector. JHEPM 2016, 38, 53-67. [CrossRef]

107. Instrad, S.T.; Christensesn, M. Healthy Universities. The development and implementation of a holistic health promotion intervention programme especially adapted for staff working in the higher educational sector: The ARK study. Glob. Health Promot. 2018. [CrossRef]

108. Kahn, W.A. Psychological conditions of personal engagement and disengagement at work. Acad. Manag. J. 1990, 33, 692-724.

109. May, D.R.; Gilson, R.L.; Harter, L.M. The psychological conditions of meaningfulness, safety and availability and the engagement of the human spirit at work. J. Occup. Organ. Psychol. 2004, 77, 11-37. [CrossRef]

110. Kim, W.; Khan, G.; Wood, J.; Mahmood, M. Employee Engagement for Sustainable Organizations: Keyword Analysis Using Social Network Analysis and Burst Detection Approach. Sustainability 2016, 8, 631. [CrossRef]

111. Maree, J.G.; Di Fabio, A. Integrating Personal and Career Counseling to Promote Sustainable Development and Change. Sustainability 2018, 10, 4176. [CrossRef]

112. Di Fabio, A.; Gori, A. Developing a New Instrument for Assessing Acceptance of Change. Front. Psychol. 2016, 7, 149. [CrossRef]

113. Di Fabio, A.; Tsuda, A. The Psychology of Harmony and Harmonization: Advancing the Perspectives for the Psychology of Sustainability and Sustainable Development. Sustainability 2018, 10, 4726. [CrossRef]

114. Di Fabio, A.; Rosen, M.A. Opening the Black Box of Psychological Processes in the Science of Sustainable Development: A New Frontier. Eur. J. Sustain. Dev. 2018, 2, 47. [CrossRef]

115. Johnstone, A.; Johnston, L. The relationship between organizational climate, occupational type and workaholism. N. Z. J. Psychol. 2005, 34, 181-188.

116. Böckerman, P.; Bryson, A.; Ilmakunnas, P. Does high involvement management improve worker wellbeing? J. Econ. Behav. Organ. 2012, 84, 660-680. [CrossRef]

(C) 2019 by the authors. Licensee MDPI, Basel, Switzerland. This article is an open access article distributed under the terms and conditions of the Creative Commons Attribution (CC BY) license (http://creativecommons.org/licenses/by/4.0/). 